\title{
Local Herbs Used in Concoction for Herbal Rice Preparation by Kelantan Siamese Community in Malaysia
}

\author{
Karunakaran, T., Aweng, E.R.* \\ Faculty of Earth Science, Universiti Malaysia Kelantan Jeli Campus, \\ Locked Bag No. 100, 17600 Jeli, Kelantan \\ Received 22 June 2017 \\ Revised 19 October 2017; Accepted 16 May 2018
}

\begin{abstract}
Herbs play a critical role, mainly as food source and supplementary source of natural medicine. In Malaysia there are numerous communities and ethnic groups who are still performing the use of herb as a part of their daily cuisine. One such community in Malaysia is the Siamese community of Kelantan, located on northern part of Kelantan, adjoining to Thailand. This community has historic tradition of consuming herbs with medicinal value. They consume a large number of herbs as concoction in rice cooking, also known as 'herbal rice'. This study was piloted to survey and record the type and parts of herbs used in the concoction. The current study was conducted via in-depth interview with local people from three village in Kelantan namely Kampung Kuang, Tanah Merah, Kampung Pasir Puteh, Tumpat dan Kampung Mentua, Tumpat, Kelantan. Total 45 herbs belonged to 24 families were documented. The parts of herb being consumed and used in concoction were leaves, stem, stalk, flower and rhizome.
\end{abstract}

Keywords: Herbal rice, concoction, herbs, Siamese, in-depth interview.

\section{Introduction}

Herbs and spices are intrinsic element of Asian values in various aspects. Even though herbs are common, extend of their uses as parts of the Asians' livelihood are vast compared to any other culture. Such herbs, not only serves as a culinary secret recipe but goes beyond the sensory aspects towards much valued aspects such as medicine, nutrition, flavoring,

\footnotetext{
*Corresponding author. Tel.: 609-9477033.

Email: aweng@umk.edu.my

https://doi.org/10.25073/2588-1140/vnunst.4517
}

beverages, dyeing, repellents, natural fragrances and as natural cosmetic products [1]. However, it is evident that herb in food is a good and safe way to achieve substantial amount of nutrition required by the human body, through a balanced and varied diet that consist of herbs and other green food. In overall, nutrition is defined as the consumption of food sources to attain valued nutrients, vitamins and minerals for normal growth, reproduction and health. Food consumption as described earlier is for the purpose of sourcing the body with sufficient stock of energy for daily living and activity. 
In addition, nutrients are the crucial components in maintaining the well-being of the human biological system at cellular level. Nutrients are generally divided into organic (contain carbon) and inorganic (includes minerals and water) [2]. Nutrients can also be classified as essential and nonessential nutrients. Essential nutrients are those desired for growth and development of an organism. Essential nutrients for instance are water, amino acids (e.g.; histidine, leucine, lysine, methionine, etc.), vitamins (e.g.; Ascorbic acid, Vit A, D, E, K), riboflavin, carbohydrate, fat, protein, fatty acids (e.g.; Linoleic), minerals (e.g.; $\mathrm{Ca}, \mathrm{P}, \mathrm{Mg}, \mathrm{Fe}$, etc.). The phenolic compounds are one of the essential nutrients where the bioactive food constituents are highly prized for their health benefits. They are also known as the herbs secondary metabolites. Among the component of the bioactive food constituents, polyphenolics are one of the most prized elements. They basically comprise of phenolic acids (e.g.; benzoic acid, caffeic acid, gallic acid, vanilic acid, courmaric acid, etc.), flavonoids (e.g.; aurones, chalcones, flavones, flavanones, etc.), tannins, etc. [3].

Apart from that, non-essential nutrients, known as bioactive food constituents are those which are not required for growth and development. Non-essential nutrients such as non-essential amino acids are those the body can synthesize from other amino acids, thus it is not necessarily acquired from external source. Examples of non-essential amino acids are: alanine, arginine, cysteine, glutamic acid, glycine, proline, tyrosine, etc. [4].

Recently, herbs with rich antioxidant properties have gained popularity due to the important prominence of antioxidant constituents in maintaining the well-being of human body. The term "antioxidant" refers to the action of a constituent that controls oxidative compounds from oxidizing. The phenolic compounds contain hydroxyl groups that provide upsurge to antioxidant potential or reducing ability. This ability is considered important in shielding the body from oxidative defects caused by 'reactive oxygen species' (ROS). Another reason why many scientists and researchers sited great attention to antioxidant constituents is due to the association of these constituents as to serve as an ailment to chronic diseases (cancer, diabetes, Alzheimer's disease, arthritis, Parkinson's disease and multiple sclerosis), These diseases have been thought to be prompted by 'reactive oxygen species' (ROS) [3].

The numerous uses of herbs in daily living have initiated the need to survey and record their types as well as to study their essential constituents and the health benefits such as the antioxidant activity, digestive stimulation action, anti-inflammatory, antimicrobial, hypolipidemic, antimutagenic effects and also anti-carcinogenic properties [5, 6].

As for Kelantan Siamese community, these herbs are familiarized in daily food consumption through herbal rice preparation where herbs are added to rice and consumed as 'herbal rice'. The practice have existed for centuries and passed down from one generation to another. Some examples of the herbs used in preparation of herbal rice in the local cuisine are Clitoria ternatea, Curcuma zanthorrhiza, Curcuma longa, Morinda citrofolia, Sauropus androgynous and etc. [7].

Thus, this study explored and provided insights into the never before known type of herbs used by the Siamese community, the types of plants being mixed in the concoction for herbal rice preparation in each of the three village of Siamese community of Kelantan. It provides new data of the trend of herbal plant uses, the uses of different parts of the plants and the richness of plant species and families naturally available in the community surroundings. By surveying and recording types of herbs used by Siamese community as herbal rice concoction expectantly can be used as a reference point to determine the nutritional value, antioxidant content, toxicity level, anticancer potential, optimum and safe ratio of the herbal concoction. 


\section{Materials and methods}

Survey and interview was conducted on 15 respondents, 5 respondents $(5$ elder individuals with deep knowledge on the practice of Herbal Rice preparation) from each village namely Kampung Pasir Puteh, Cabang Empat, Tumpat, Kampung Kuang, Tanah Merah and Kampung Mentua, Pengkalan Kubor, Kelantan, Malaysia (Figure 1). The respondents were chosen based on their knowledge in identifying and using herbal plants in their daily life, especially in herbal rice preparation. The respondents helped to identify and collect the plant sample around their village and explained their common name and the parts used in herbal rice preparation. Herbs samples were also collected to identify type and name. Herbs samples were identified by Dr. Shamsul Khamis (Senior Lecturer/Botanist) from Universiti Putra Malaysia and Mr. Ahmad Fitri, from Institute of Environmental Science and Natural Resource, Faculty of Science and Technology, Universiti Kebangsaan Malaysia.

The richness of plant family among the consumption of the Siamese community was calculated by:

$$
\text { (\%) plant family richness }=\frac{\text { No. of plants identified within a family } \times 100}{\text { Total number of plants identified }}
$$

Meanwhile, the percentage of plant parts being used in overall was calculated by;

$$
\text { (\%) } \text { plant parts being used }=\frac{\text { No. of plant of the same part usage }}{\text { Total number of plants identifies }}
$$

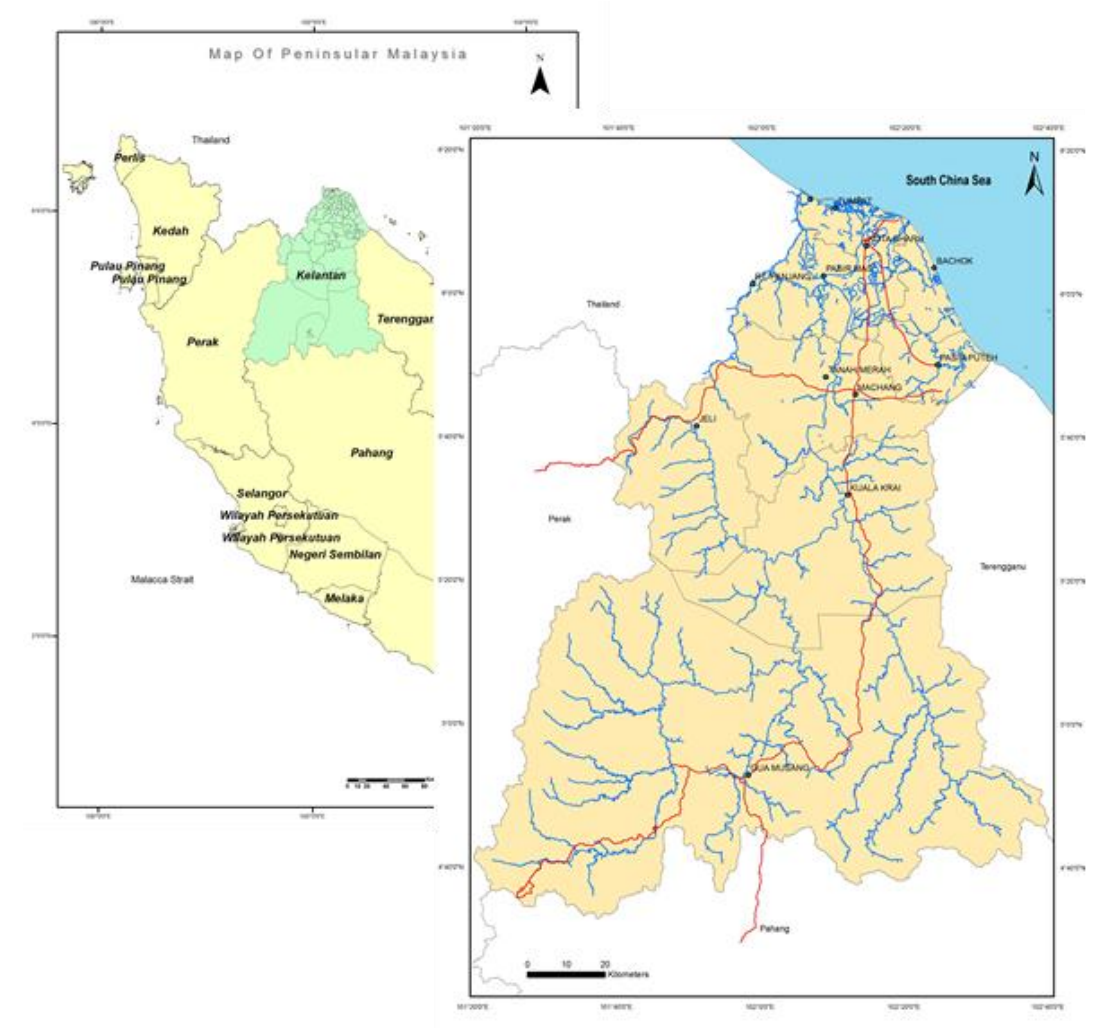

Figure 1. Study sites. 


\section{Results and discussion}

The types of herb and the parts consumed by Siamese community in Northern parts of Kelantan were documented along with their scientific names. A total of 45 herbs belonging to 24 families were documented. The parts of herbs consumed were leaves, stem, stalk, flower and rhizome. All the herbs were normally concocted in different ratios respective to each of the three villages studied under Siamese community. The highest number of herbs consumed in a single concoction was found in Kampung Mentua, Pengkalan Kubor (Village 1-V1), followed by Kampung Pasir Puteh, Cabang Empat, Tumpat, Kelantan, Malaysia (Village 2-V2), Tumpat and Kampung Kuang, Tanah Merah, Kelantan, Malaysia (Village 3-V3) had the least number of herbs used in the concoction among the three villages (Table 1).

Table 1. Type of herbal plant scientific name, family name and parts consumed in each village

\begin{tabular}{|c|c|c|c|c|}
\hline $\begin{array}{l}\text { Family name } \\
\text { scientific name }\end{array}$ & Local name & V1 & $\mathrm{V} 2$ & V3 \\
\hline $\begin{array}{l}\text { Family: Acanthaceae } \\
\text { Acanthus ebracteatus }\end{array}$ & Khem Pla Mor & $\mathrm{L}$ & - & - \\
\hline $\begin{array}{l}\text { Family: Annonaceae } \\
\text { Desmos chinensis } \\
\text { Friesodielsia sp. } \\
\text { Uvaria Grandiflora }\end{array}$ & $\begin{array}{l}\text { Pelau nyai } \\
\text { Pelau } \\
\text { Num Ngua }\end{array}$ & $\begin{array}{l}\mathrm{L} \\
\mathrm{L} \\
-\end{array}$ & $\begin{array}{l}\mathrm{L} \\
\mathrm{L}\end{array}$ & $\begin{array}{l}- \\
L\end{array}$ \\
\hline $\begin{array}{l}\text { Family: Asparagaceae } \\
\text { Dracaena umbratica Ridl. }\end{array}$ & Khe Niau Sang & $\mathrm{L}$ & - & - \\
\hline $\begin{array}{l}\text { Family: Bignoniaceae } \\
\text { Oroxylum indicum }\end{array}$ & Phae Kaa & - & $\mathrm{L}$ & $\mathrm{L}$ \\
\hline $\begin{array}{l}\text { Family: Costaceae } \\
\text { Cheilocostus speciosus }\end{array}$ & Eang & $\mathrm{L}$ & - & - \\
\hline $\begin{array}{l}\text { Family: Cucurbitaceae } \\
\text { Coccinia grandis }\end{array}$ & Tam Loeng & - & $\mathrm{L}$ & $\mathrm{L}$ \\
\hline $\begin{array}{l}\text { Family: Euphorbiaceae } \\
\text { Mallotus paniculatus (Lam.) } \\
\text { Sauropus androgynus }\end{array}$ & $\begin{array}{l}\text { Lang Khau } \\
\text { Pak Waan }\end{array}$ & L & $\begin{array}{l}\mathrm{L} \\
\mathrm{L}\end{array}$ & $\begin{array}{l}- \\
\mathrm{L}\end{array}$ \\
\hline $\begin{array}{l}\text { Family: Fabaceae } \\
\text { Clitoria ternatea }\end{array}$ & Anchan & $\mathrm{F}$ & $\mathrm{F}$ & $\mathrm{F}$ \\
\hline $\begin{array}{l}\text { Family: Flagellariaceae } \\
\text { Flagellaria indica }\end{array}$ & Wai Ling & $L \& S$ & - & - \\
\hline $\begin{array}{l}\text { Family: Lamiaceae } \\
\text { Vitex negundo L. } \\
\text { Vitex rotundifolia L. }\end{array}$ & $\begin{array}{l}\text { Khai Now Meing } \\
\text { Kunthi }\end{array}$ & $\bar{L}$ & $\begin{array}{l}\mathrm{L} \\
\mathrm{L}\end{array}$ & - \\
\hline $\begin{array}{l}\text { Family: Lauraceae } \\
\text { Cinnamomum camphora } \\
\text { Litsea tomentosa }\end{array}$ & $\begin{array}{l}\text { Kechit } \\
\text { Chom Pluak }\end{array}$ & $\begin{array}{l}- \\
\mathrm{L}\end{array}$ & $\begin{array}{l}\mathrm{L} \\
\mathrm{L}\end{array}$ & $\begin{array}{l}- \\
-\end{array}$ \\
\hline $\begin{array}{l}\text { Family: Leguminosae } \\
\text { Cassia / Senna alata L. } \\
\text { Flemingia macrophylla (Wild.) Merr. }\end{array}$ & $\begin{array}{l}\text { Chum Hat } \\
\text { Chemut phra }\end{array}$ & $\begin{array}{l}\mathrm{L} \\
\mathrm{L}\end{array}$ & $\begin{array}{l}\mathrm{L} \\
\mathrm{L}\end{array}$ & - \\
\hline $\begin{array}{l}\text { Family: Lygodaceae } \\
\text { Lygodium microphyllum }\end{array}$ & Rebu nyung & $\mathrm{L}$ & - & - \\
\hline
\end{tabular}




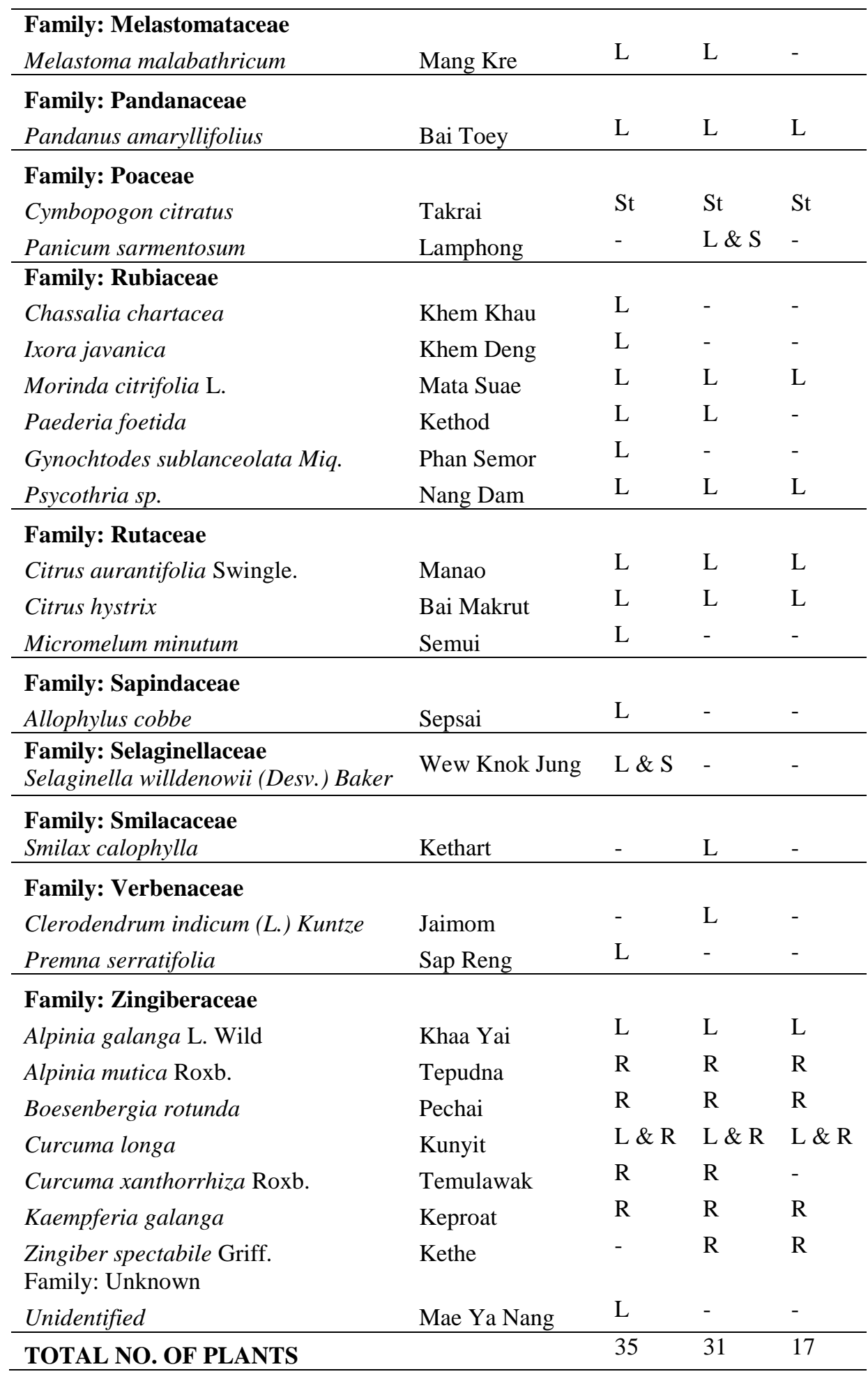

*F=flower, L=leaf, R=rhizome, $\mathrm{S}=$ stem, $\mathrm{St}=$ stalk and $(-)=$ not consumed. V1= Kampun Mentua, Pengkalan Kubor, V2= Kampung Pasir Puteh, Tumpat and V3= Kampung Kuang, Tanah Merah. 
Other than being used as a part of concoction in herbal rice preparation, most of the herbs documented from the three villages are consumed as salad or cooked with other ingredients such as common vegetable, fish and chicken as well as in tea and sweet delicacies. In general, the villagers consume herbs for general health benefit because they believe the herbs would safeguard the well-being of their body and protect them from diseases. For instance, the Siamese community uses Achantus ebracteatus as ailment for body itchiness, Litsea tomentosa are used to reduce swellings, Cassia alata L. used as ailemt in malaria, skin itchiness and sinusitis and Morinda citrifolia for controlling blood pressure and diabetes (Table 2).

Table 2. List of plants and its traditional uses in Siamese community

\begin{tabular}{|c|c|c|}
\hline Plant (Scientific Name) & Siamese Name & Traditional uses \\
\hline \multicolumn{3}{|l|}{ F:Acanthaceae } \\
\hline Achanthus ebracteatus [AE] & Khem Pla Mor & Used as ailment for body itchiness \\
\hline \multicolumn{3}{|l|}{ F: Annonaceae } \\
\hline Desmos chinensis [DC] & Pelau Nyai & \multirow{3}{*}{$\begin{array}{l}\text { Used for stomach ache, flatulence and } \\
\text { tendon pain }\end{array}$} \\
\hline Friesodielsia sp. [F.sp] & Pelau & \\
\hline Uvaria grandiflora [UG] & Num Ngua & \\
\hline \multicolumn{3}{|l|}{ F: Asparagaceae } \\
\hline $\begin{array}{l}\text { Dracaena umbratica Ridl. } \\
\text { [DU] }\end{array}$ & Khe Niau Sang & Salad and for cooking \\
\hline \multicolumn{3}{|l|}{ F: Bignoniaceae } \\
\hline Oroxylum indicum [OI] & Phae Kaa & Salad and for cooking \\
\hline \multicolumn{3}{|l|}{ F: Costaceae } \\
\hline Cheilocostus speciosus [CS] & Eang & Salad and for cooking \\
\hline \multicolumn{3}{|l|}{ F: Cucurbitaceae } \\
\hline Coccinia grandis $[\mathrm{CG}]$ & Tam Loeng & Salad and for cooking \\
\hline \multicolumn{3}{|l|}{ F: Euphorbiaceae } \\
\hline $\begin{array}{l}\text { Mallotus paniculatus (Lam.) } \\
{[\mathrm{MP}]}\end{array}$ & Lang Khau & -Not available- \\
\hline Sauropus androgynus [SA] & Phak Wan & Salad and for cooking \\
\hline \multicolumn{3}{|l|}{ F: Fabaceae } \\
\hline Clitoria ternatea $[\mathrm{CT}]$ & Dok Anchan & $\begin{array}{l}\text { Food colouring, salad and herbal } \\
\text { drink }\end{array}$ \\
\hline \multicolumn{3}{|l|}{ F: Flagellariaceae } \\
\hline Flagellaria indica $[\mathrm{FI}]$ & Wai Ling & -Not available- \\
\hline \multicolumn{3}{|l|}{ F: Lamiaceae } \\
\hline Vitex negundo L. [VN] & $\begin{array}{l}\text { Khai Now } \\
\text { Meing }\end{array}$ & -Not available- \\
\hline Vitex trifolia L. [VT] & Kunthi & Traditional dishes and sweets \\
\hline \multicolumn{3}{|l|}{ F: Lauraceae } \\
\hline $\begin{array}{l}\text { Cinnamomum camphora } \\
{[\mathrm{CC}]}\end{array}$ & Kechit & Salad and for cooking \\
\hline Litsea tomentosa [LT] & $\begin{array}{l}\text { Phiya Chom } \\
\text { Pluak }\end{array}$ & Used to reduce swellings \\
\hline
\end{tabular}




\begin{tabular}{|c|c|c|}
\hline Plant (Scientific Name) & Siamese Name & Traditional uses \\
\hline \multicolumn{3}{|l|}{ F: Leguminosae } \\
\hline Cassia alata L. [CA] & Chum Hat & $\begin{array}{l}\text { Used as ailment in malaria, itchiness } \\
\text { and sinusitis }\end{array}$ \\
\hline $\begin{array}{l}\text { Flemingia macrophylla } \\
\text { (Wild.) Merr. [FM] }\end{array}$ & Chemut Phra & -Not available- \\
\hline $\begin{array}{l}\text { F: Lygodaceae } \\
\text { Lygodium microphyllum } \\
\text { [LM] }\end{array}$ & Rebu Nyung & Ailment for skin itchiness \\
\hline \multicolumn{3}{|l|}{ F: Melastomataceae } \\
\hline $\begin{array}{l}\text { Melastoma malabathricum } \\
{[\mathrm{MM}]}\end{array}$ & Khering & -Not available- \\
\hline \multicolumn{3}{|l|}{ F: Pandanaceae } \\
\hline $\begin{array}{l}\text { Pandanus amaryllifolius } \\
\text { [PA] }\end{array}$ & Bai Panan & Food flavouring \\
\hline \multicolumn{3}{|l|}{ F: Poacea } \\
\hline Cymbopogon citratus [CyC] & Ta khrai & Used in cooking and as herbal drink \\
\hline Panicum sarmentosum [PaS] & Nya Lamphong & -Not available \\
\hline \multicolumn{3}{|l|}{ F: Rubiaceae } \\
\hline Chassalia chartacea $[\mathrm{ChC}]$ & Khem Khau & $\begin{array}{l}\text { General traditional medicine and for } \\
\text { tendon pain }\end{array}$ \\
\hline $\begin{array}{l}\text { Gynochtodes sublanceolata } \\
\text { Miq. [GS] }\end{array}$ & Phan Semor & -Not available- \\
\hline Ixora javanica [IJ] & Khem Deng & Used for tendon pain \\
\hline Morinda citrifolia $[\mathrm{MC}]$ & Bai Jor & $\begin{array}{l}\text { Used as ailment for high blood } \\
\text { pressure, diabetes and as salad }\end{array}$ \\
\hline Paederia foetida $[\mathrm{PF}]$ & Kethod & $\begin{array}{l}\text { General traditional medicine and also } \\
\text { consumed as salad }\end{array}$ \\
\hline $\begin{array}{l}\text { Psycothria sp. [P.sp] } \\
\text { F: Rutaceae }\end{array}$ & Nang Dam & -Not available- \\
\hline $\begin{array}{l}\text { Citrus aurantifolia Swingle } \\
\text { [CAS] }\end{array}$ & Manau & $\begin{array}{l}\text { Used in cooking and drink } \\
\text { preparation }\end{array}$ \\
\hline Citrus hystrix $[\mathrm{CH}]$ & Makrud & $\begin{array}{l}\text { Used as general traditional medicine. } \\
\text { Used as mosquito and snake repellent. }\end{array}$ \\
\hline $\begin{array}{l}\text { Micromelum minutum } \\
{[\mathrm{MiM}]}\end{array}$ & Semui & $\begin{array}{l}\text { Used as general traditional medicine } \\
\text { and also as salad }\end{array}$ \\
\hline F: Sapindaceae & & \\
\hline $\begin{array}{l}\text { Allophylus cobbe }[\mathrm{AC}] \\
\text { F: Selaginellaceae }\end{array}$ & Sepsai & -Not available- \\
\hline Selaginella alutacia $[\mathrm{SeA}]$ & $\begin{array}{l}\text { Wew Knok } \\
\text { Jung }\end{array}$ & General traditional medicine \\
\hline F: Smilacaceae & & \\
\hline $\begin{array}{l}\text { Smilax calophylla }[\mathrm{SC}] \\
\text { F: Verbenaceae }\end{array}$ & Kethart & General traditional medicine \\
\hline $\begin{array}{l}\text { Clerodendrum indicum (L.) } \\
\text { Kuntze }[\mathrm{CI}]\end{array}$ & $\begin{array}{l}\text { Mai Thau } \\
\text { Jaimom }\end{array}$ & $\begin{array}{l}\text { General traditional medicine and also } \\
\text { as salad }\end{array}$ \\
\hline
\end{tabular}




\begin{tabular}{|c|c|c|}
\hline Plant (Scientific Name) & Siamese Name & Traditional uses \\
\hline Premna serratifolia $[\mathrm{PrS}]$ & Sap Reng & -Not available- \\
\hline \multicolumn{3}{|l|}{ F: Zingiberaceae } \\
\hline $\begin{array}{l}\text { Alpinia galanga L. (Wild.) } \\
\text { [AG] }\end{array}$ & Kha & Used in cooking \\
\hline Alpinia mutica Roxb. [AM] & Tepudna & Salad \\
\hline Boesenbergia rotunda [BR] & Pechai & Used as salad and in cooking \\
\hline Curcuma longa $[\mathrm{CL}]$ & Khamin & $\begin{array}{l}\text { Used as ailment for gastric and also in } \\
\text { cooking }\end{array}$ \\
\hline $\begin{array}{l}\text { Curcuma xanthorrhiza Roxb. } \\
{[\mathrm{CX}]}\end{array}$ & Khamin Khau & Salad \\
\hline Kaempferia galanga $[\mathrm{KG}]$ & Keproat & $\begin{array}{l}\text { Used as treatment for internal and } \\
\text { external wound }\end{array}$ \\
\hline $\begin{array}{l}\text { Zingiber spectabile Griff. } \\
\text { [ZS] }\end{array}$ & Kethe & Salad \\
\hline \multicolumn{3}{|l|}{ F:Unknown } \\
\hline Species X & Mae Ya Nang & $\begin{array}{l}\text { General traditional medicine and } \\
\text { consumed as salad }\end{array}$ \\
\hline
\end{tabular}

The villagers have strong belief that the various types of plants are source of nutrition, energy, revitalize and rejuvenate their body to stay energetic in daily life. As shown in Table 1.2 , the medicinal benefit of each plant among the community is still vague, however due to the ancestral practice of consuming the plants as mixture or concoction, a strong believe has been established within their community. This also means the fact of nutrition of the traditional practice of herbal rice concoction has a good potential to be explored for general health benefit.

The recorded data (Figure 2) showed that herbs from the family Rubiaceae and Zingiberaceae denotes most abundant species consumed by Siamese community. Both the family groups represent 13.33 and $15.56 \%$ of total herbs consumed, respectively. This displays that the two families have the most number of herbs in comparison to all other families documented.

The plausible reason for the widespread use of herbs from the two family groups can be related to the availability of the herbs and the large number of species diversity within each family. Rubiaceae has been known to cover 630 genera and 1300 species, meanwhile Zingiberaceae is likely to have 52 genera and 1500 species worldwide, respectively [8, 9]. The comparative richness of the two families' species especially in tropical regions is a significant reason for the widespread use of the herbs labelled above.

The usage of plant parts among the three villages were the same, except for the types of plants being consumed in each village, for example V1 used more plants in comparison to $\mathrm{V} 2$ and V3. Based on the data recorded on the part being used in herbal rice preparation, it was found that the percentage of parts used varied vastly. Among the herbs parts being consumed by Siamese community (Figure 3), roughly $77.08 \%$ of the consumption was on the leaf portion followed by $12.50 \%$ of rhizome and $6.25 \%$ of stem. While, stalk and flower usage represents $2.08 \%$ respectively. Likewise a research done by [10] on various herbs used in Asian traditional medicine exhibited that leaf portion of herbs are greatly utilized especially in South East Asia. 


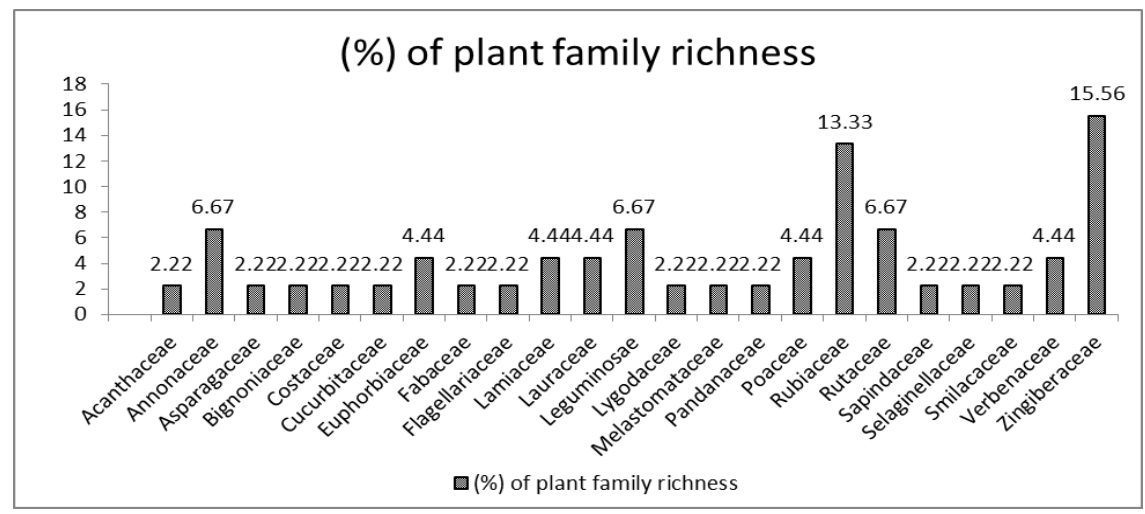

Figure 2. The percentage of plant family richness in the consumption for herbal rice preparation.

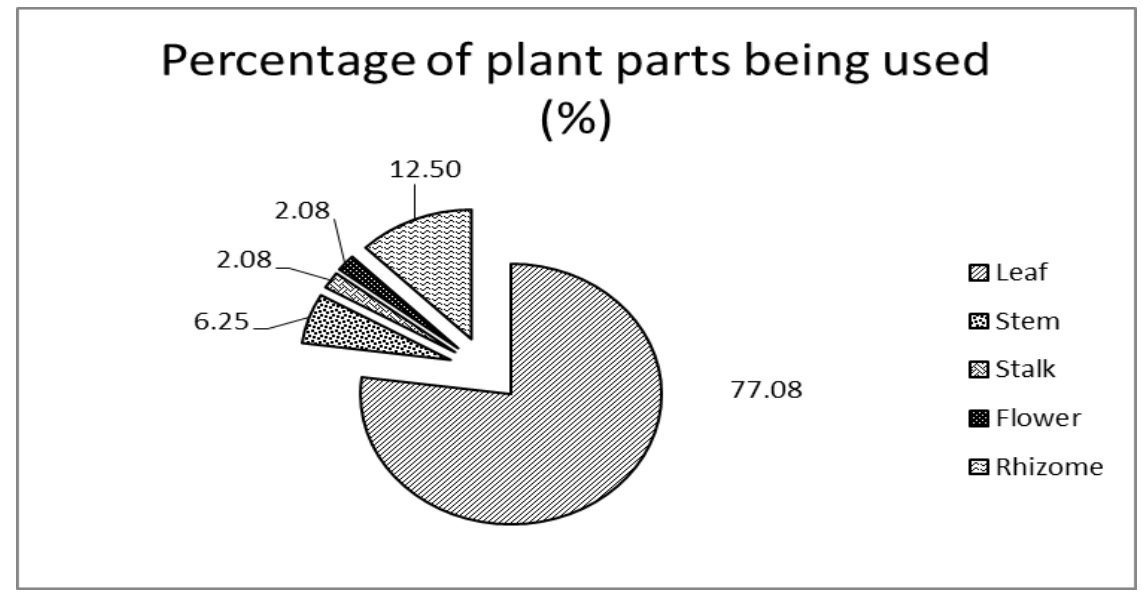

Figure 3. Percentage $(\%)$ of plant parts being used in herbal concoction by Siamese community.

The findings denote that the uses of herbal plants are rich and extensive among the Siamese community and their knowledge of uses are still vague to the scientific world. There are little known studies pertaining to the herbal mixture especially of large combination as the Siamese community practice.

\section{Conclusion}

This study has successfully recorded 45 types of herbs that are used by the Siamese community in three main villages which have the largest Siamese community in Kelantan. The plants are largely used in preparing herbal rice. The 45 types of plants were successfully identified for their scientific names, family names and sorted into 24 different family groups. The findings also present their local names and the parts of each plant that are used for the herbal rice preparation. Leave portion of plants are highly used compared to other parts of plant. The family of Zingiberaceae and Rubiaceae were found to be the extensively utilized group of family in the studied location. We also have found out that most of the medicinal benefits of plants still unknown among the community and consumption are based on ancestral knowledge and advice.

\section{Acknowledgement}

We would like to express our deepest appreciation to the Ministry of Higher 
Education for providing funding through the Fundamental Research Grant Scheme [R/FRGS/A08.00/00244A/003/2014/000181] to complete this research. We are also grateful to Dr. Shamsul Khamis (Senior Lecturer/Botanist) from Universiti Putra Malaysia and Mr. Ahmad Fitri, from Institute of Environmental Science and Natural Resource, Faculty of Science and Technology, Universiti Kebangsaan Malaysia for identifying the plants. The paper would not have been possible without the help from those individuals.

\section{References}

[1] Djeridane, A., Yousfi, M., Nadjemi, B., Boutassouna, D., Stocker, P. \& Vidal, N. (2006). Antioxidant activity of some Algerian medicinal plants extracts containing phenolic compounds. Food Chem, 97, 654-660.

[2] Stipanuk, M. H. (2006). Nutrients: History and definitions (essential and nonessential). Biochemical, physioligical, molecular aspects of human nutrition. (2nd ed.). Philadelphia, PA, USA.: Saunders, Elsevier Inc.

[3] Jeffery, E. H., Kundrat, S. M. \& Keck, A. S. (2006). Nutrients: Nonessential food components with health benefits (essential and nonessential). Biochemical, physiological, molecular aspects of human nutrition (2nd ed.). Philadelphia, PA, USA.: Saunders, Elsevier Inc.
[4] King, F. S., Burgess, A., Quinn, V. J. \& Osei, A. K. (2015). Nutrition for developing countries: Oxford University Press.

[5] Aaby, K., Hvattum, E. \& Skrede, G. (2004). Analysis of flavonoids and other phenolic compounds using high-performance liquid chromatography with coulometric array detection: Relationship to antioxidant activity. Journal of the Agricultural and Food Chemistry, 52, 4595-4603.

[6] Luo, Y., Cai, Q., Sun, M. \& Corke, H. (2004). Antioxidant activity and phenolic compounds of 112 traditional Chinese medicinal plants associated with anticancer. Life Sciences, 74, 2157-2184.

[7] Aweng, E. R., Noor Syuhadah, S., Norashikin, M. F., Ismail, A. A., Nur Izzati, S. \& Ahmad Fadli, A. S. (2014). Nutritional value of the concoction of Sauropus androgynus, Morinda citrifolia, Clitoria ternatea, Curcuma zanthorrhiza and Curcuma longa used for herbs rice. Journal of Tropical Resources and Sustainable Science, 2, 47-52.

[8] Kala, S. C. (2015). Medicinal attributes of family Rubiaceae. International Journal of Pharmacy and Biological Science, 5(2), 179-181.

[9] Sirirugsa, P. (1998). Thai Zingiberaceae: Species diversity and their uses. Paper presented at the International Conference on Biodiversity and Bioresources: Conservation and Utilization, Phuket, Thailand.

[10] Akarasereenont, P., Datiles, M. J., Lumlerdkij, N., Yaakob, H., Prieto, J. M. \& Heinrich, M. (2015). A South-East Asian Perspective on Ethnopharmacology. Ethnopharmacology, 317

\title{
Các loại thảo mộc địa phương được sử dụng trong pha chế để chế biến gạo thảo dược của cộng đồng Kelantan Siamese ở Malaysia
}

\author{
Karunakaran, T., Aweng, E.R. \\ Khoa Khoa học Trái đất, Đại học Malaysia Kelantan Jeli Campus, \\ Locked Bag No. 100, 17600 Jeli, Kelantan
}

Tóm tắt: Các loài cây thảo mộc đóng vai trò quan trọng trong việc cung cấp nguồn thực phẩm và thành phần bổ sung cho dược phẩm tự nhiên. Tại Malaysia, nhiều nhóm cộng đồng dân tộc thường sử 
dụng các loại cây thảo mộc như là một dạng thực phẩm hàng ngày, cụ thể là nhóm cộng đồng Siamese nằm ở vùng phía bắc Kelantan tiếp giáp với Thái Lan. Cộng đồng này có truyền thống lịch sử lâu đời trong việc sử dụng các loại cây thảo mộc như là một dạng giá trị dược phẩm. Cộng đồng này cũng sử dụng nhiều loại cây thảo mộc cho chế biến trong các bữa ăn, được gọi là "gạo thảo mộc". Nghiên cứu này hướng tới việc điều tra và ghi nhận các dạng và bộ phận của cây thảo mộc được dùng trong chế biến. Nghiên cứu này được thực hiện thông qua phỏng vấn sâu với cộng đồng địa phương từ ba làng tại Kelantan, bao gồm Kampung Kuang, Tanah Merah, Kampung Pasir Puteh, Tumpat dan Kampung Mentua, Tumpat, Kelantan. Kết quả ghi nhận có tổng cộng 45 cây thảo mộc thuộc 24 nhóm được ghi nhận. Các bộ phận của cây thảo mộc thường được sử dụng trong chế biến bao gồm lá, thân, cuống, hoa và rễ.

Tư khóa: Gạo thảo mộc, pha chế, thảo mộc, Siamese, phỏng vấn sâu. 